\title{
Steroid secretion rates and plasma binding activity in androstenedione-immune ewes with an autotransplanted ovary
}

\author{
B. K. Campbell†, R. J. Scaramuzzi*, J. A. Downing* and G. Evans \\ Department of Animal Husbandry, University of Sydney, Sydney, NSW 2046, Australia; and \\ *CSIRO Division of Animal Production, Prospect, NSW 2148, Australia
}

\begin{abstract}
Summary. Mature Merino ewes in which the left ovary and its vascular pedicle had been autotransplanted to the neck were divided into control $(\mathrm{N}=5)$ and immunized groups $(\mathrm{N}=6)$. The immunized ewes were treated $\left(2 \mathrm{ml}\right.$ s.c.) with Fecundin ${ }^{\circledR} 1$ and 4 weeks before the start of blood sampling. Ovarian and jugular venous blood was collected every $10 \mathrm{~min}$ at two stages of the follicular phase $(21-27 \mathrm{~h}$ and $38-42 \mathrm{~h}$ after i.m. injection of $125 \mu \mathrm{g}$ of a prostaglandin (PG) analogue) and during the mid-luteal phase ( $8 \mathrm{~h}$ at 15-min intervals). The ewes were monitored regularly for luteal function and preovulatory LH surges. Hormone concentrations and anti-androstenedione titres were assayed by RIA and ovarian secretion rates of oestradiol-17 $\beta$, progesterone and androstenedione were determined.

After the booster immunization, progesterone increased simultaneously with titre in immunized ewes, reaching $30 \mathrm{ng} / \mathrm{ml}$ at the time of $P G$ injection when median titre was 1:10 000. All ewes responded to PG with LH surges $42-72 \mathrm{~h}$ later: 2 of the immunized ewes then had a second LH surge within 3-4 days at a time when peripheral progesterone values were $2-3 \mathrm{ng} / \mathrm{ml}$. The frequency of steroid and $\mathrm{LH}$ pulses was greater in immunized ewes $(P<0.05)$ during the luteal phase but not the follicular phase. The secretion rate of androstenedione was 6-10 times greater (19-37 ng/min; $P<0.001)$ in immunized ewes at all sampling stages. Progesterone secretion rates were 3 times greater $(16 \mu \mathrm{g} / \mathrm{min} ; P<0.001)$ during the luteal phase in immunized ewes. The amplitude of oestradiol pulses was significantly reduced in immunized ewes (4.8 vs $2.1 \mathrm{ng} / \mathrm{min}$ at $+24 \mathrm{~h}$ and 6.5 vs $2.8 \mathrm{ng} / \mathrm{min}$ at $+40 \mathrm{~h}$ in control and immunized ewes, respectively: $P<0.05$ ) during the follicular phase. However, the mean secretion rate of oestradiol at each phase of the cycle was not significantly different between treatment groups. Analysis of bound and free steroid using polyethylene glycol showed that $>98 \%$ of peripheral and ovarian venous androstenedione and $86 \%$ of peripheral progesterone was bound in immunized ewes but there was no appreciable binding $(<0.1 \%)$ in control ewes. Similarly, $50 \%$ of ovarian venous oestradiol was bound in immunized ewes compared to $15 \%$ in control ewes.

We conclude that immunization against androstenedione increases the secretion rate of androstenedione and progesterone but not of oestradiol. The enhanced plasma binding of progesterone and oestradiol in androstenedione-immunized ewes may interfere with the biological action of these steroids, thus providing an explanation for the elevated LH pulse frequently observed in immunized ewes.
\end{abstract}

Keywords: androstenedione-immunity; steroid secretion; LH; plasma binding; sheep

†Present address: Department of Obstetrics and Gynaecology, MRC Unit for Reproductive Biology, 37 Chalmers St, Edinburgh EH3 9EW, UK. 


\title{
Introduction
}

It is well established that active or passive immunization against oestrogens and/or androgens (reviews: Scaramuzzi \& Hoskinson, 1984; Webb et al., 1984) and active immunization against progesterone (Thomas et al., 1987) increases ovulation rate in sheep. Despite using controlled immunization against androstenedione as a commercial means for increasing litter size (Scaramuzzi et al., 1983), the mechanisms responsible for this increase in ovulation rate and the associated endocrine changes are unclear. Animals immunized against oestrogens, androgens and progesterone all have increased concentrations of $\mathrm{LH}$ associated with increases in $\mathrm{LH}$ pulse frequency and/or amplitude (Martensz et al., 1979; Martensz \& Scaramuzzi, 1979; Pathiraja et al., 1984; Thomas et al., 1987; Campbell, 1988). FSH concentrations, however, are elevated in oestrogen-immune animals (Martensz et al., 1979; Pant, 1978; Pathiraja et al., 1984) but are usually unchanged or depressed in androgen-immune ewes (Martensz et al., 1979; Martensz \& Scaramuzzi, 1979; Pathiraja et al., 1984; Campbell, 1988). The one exception to this consensus is a report of elevated FSH values in androstenedione-immune ewes (McNatty et al., 1988).

Although interference with negative feedback can explain the increase in peripheral LH concentrations in oestradiol-, oestrone- and progesterone-immune ewes, the mechanisms responsible in androgen-immune ewes are unclear. It has been generally assumed that the increase in LH values associated with androgen immunity is due to reduction of negative feedback caused by the lack of androgen precursors for oestradiol synthesis. Doubt was cast on this assumption when Scaramuzzi et al. (1980) found that oestradiol concentrations in ovarian venous plasma during the follicular phase were actually higher in androstenedione-immune ewes. This finding led to the postulation that androstenedione may exert its own feedback effects on $\mathrm{LH}$ secretion. Subsequent testing of this hypothesis with steroid-implanted ovariectomized ewes has shown that androstenedione has no effect on LH pulsatility (Martin et al., 1983). In addition it is difficult to reconcile the elevation in LH pulse frequency in the luteal phase with the elevation in peripheral luteal-phase progesterone concentrations observed in androstenedione- (Scaramuzzi et al., 1980; Campbell, 1988) and oestrone- (Scaramuzzi \& Hoskinson, 1984) immune ewes. The reasons for these increases in progesterone concentrations are also unclear, although they may be due to increased LH stimulation, an increase in the number of corpora lutea, changes in intracellular steroidogenic mechanisms or interface with metabolic clearance of steroids from the blood. Decreased metabolic clearance of testosterone has been reported for testosterone-immune rabbits (Wickings et al., 1976). The effect of immunization on steroid secretion rates has not been determined.

The aim of this study was to examine the temporal patterns of steroid secretion at different stages of the oestrous cycle in conscious ewes actively immunized against androstenedione. In addition the possibility that alterations in the partitioning of circulating steroids into bound and free fractions may occur as a result of immunization was investigated.

\section{Materials and Methods}

\begin{abstract}
Animals. The animals were mature Merino ewes (9-10 years old) in which the left ovary and its vascular pedicle had been autotransplanted to the neck (Goding et al., 1967). These consisted of 5 random-bred control ewes (AB-20 flock) and 6 Booroola ewes (AB-9 flock) not carrying the F-gene $(+/+)$. The ewes were fed a diet consisting of $1500 \mathrm{~g}$ of a pelleted ration of lucerne:oats $(60: 40 \mathrm{w} / \mathrm{w})$ three times a week. This ration contained approximately $17 \mathrm{MJ}$ gross energy $/ \mathrm{kg}$ and $14 \%$ protein.
\end{abstract}

Experimental design. The different strains of ewe were assigned to two treatment groups of 5 untreated controls ( 2 random bred and $3+1+$ Booroola) and 6 immunized ( 3 random bred and $3+1+$ Booroola) ewes. Previous investigations have shown no difference in endocrine characteristics between the two strains of ewe (Tsonis et al., 1988 ; R. J. Scaramuzzi \& D. T. Baird, unpublished observations). Immunized ewes were given their primary immunization against androstenedione- $7 \alpha$-carboxyethylthioether-human serum albumin with a DEAE-Dextran immunoadjuvant ( $2 \mathrm{ml}$ s.c.: Fecundin ${ }^{\circledR}$; Glaxo Animal Health, Boronia, Victoria, Australia) 4 weeks before the start of intensive 
blood sampling. An identical booster immunization was given 7 days before the start of blood sampling. As these ewes with ovary transplants do not cycle spontaneously, 4 'cycles' were artificially induced before the start of blood sampling, using intramuscular injections of $125 \mu \mathrm{g}$ of a synthetic analogue of prostaglandin (PG) F-2 $\alpha$ (Estrumate: ICI, Sydney, NSW, Australia) given 15-20 days apart.

Blood samples. Jugular venous blood samples were taken three times a week by venepuncture during the period of artificial 'cycles' to monitor antibody titre and luteal function.

On the day before the start of intensive blood sampling, all ewes were cannulated (Goding et al., 1967). Briefly, a polyvinyl cannula (1.4 mm i.d., $1.9 \mathrm{~mm}$ o.d.; SV102 Dural Plastics \& Engineering, Sydney, NSW, Australia) was inserted into the jugular vein, near the top of the skin loop, and positioned so that the tip was opposite the site of the jugular-ovarian vein anastomosis. The size of the cannula used was carefully chosen to ensure that the maximum flow rate of the cannula was greater than the expected maximum flow rate of the ovarian vein. A timed sample of ovarian venous blood $(5 \mathrm{ml})$ was collected into centrifuge tubes containing $100 \mathrm{IU}$ heparin in $100 \mu \mathrm{l}$ saline $(0 \cdot 154 \mathrm{M}-\mathrm{NaCl})$. The contralateral jugular vein was also cannulated.

All animals received a luteolytic dose of PG $(125 \mu \mathrm{g})$ at $15: 00 \mathrm{~h}$ on the day they were cannulated, which corresponded to Day 10 of their 'cycle'. From the time of PG injection peripheral blood samples were taken at 8-h intervals until PG $+21 \mathrm{~h}$ when the first period of intensive blood sampling commenced. Thereafter, in addition to the intensive bleeds, peripheral blood samples were taken at 2-h intervals until PG $+90 \mathrm{~h}$ and then twice daily for a further 13 days.

There were three periods of intensive blood sampling, during which both peripheral and ovarian venous blood was collected; (i) the early follicular phase for $6 \mathrm{~h}$ at 10-min intervals (i.e. $21-27 \mathrm{~h}$ after PG); (ii) the late follicular phase for $4 \mathrm{~h}$ at 10-min intervals (i.e. $38-42 \mathrm{~h}$ after PG); and (iii) the mid-luteal phase for $8 \mathrm{~h}$ at 15 -min intervals (i.e. 13 days after $P G)$.

Detection of oestrus. During the period when the ewes were undergoing their artificial 'cycles' oestrus was detected by using rams wearing Sire-Sine ${ }^{\circledR}$ harnesses. While in metabolism cages oestrus could not be detected with rams but was verified as having occurred by examination of vaginal mucus $43 \mathrm{~h}$ after PG (Turnbull et al., 1967).

Hormone assays. LH, FSH and progesterone concentrations in jugular venous blood were determined by radioimmunoassays as previously described (Campbell, 1988). Concentrations of oestradiol, androstenedione and progesterone in ovarian venous blood were determined by radioimmunoassays based on published methods (Scaramuzzi et al., 1975) and described in detail elsewhere (Campbell, 1988). Details of the assays are presented in Table 1.

The oestradiol antiserum (727) was raised in sheep against oestradiol-6-BSA. It had the following major crossreactions: oestrone $7 \%$ and oestriol, oestradiol- $17 \alpha$, testosterone, androstenedione and progesterone $<0.1 \%$. The androstenedione antiserum (2119) was raised in sheep against androstenedione-7-HSA. Its major cross-reactions

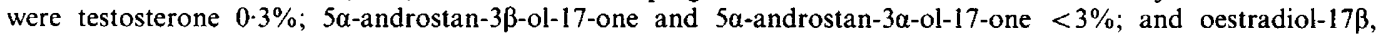
progesterone and dihydrotestosterone $<0.1 \%$. The progesterone antiserum (7943) was raised in sheep against progesterone-11-HSA. Its major cross-reactions were: $11 \alpha$-hydroxyprogesterone $17 \cdot 5 \%$; deoxycorticosterone $9.5 \%$; $5 \beta$-pregnone-3,20-dione $2 \cdot 1 \% ; 3 \beta$-pregnone-3,20-dione $2 \cdot 5 \%$; and $17 \alpha$-hydroxyprogesterone, cortisol, pregnenolone, cholesterol, androstenedione, testosterone and oestradiol- $17 \beta<0.01 \%$.

Antibody titres. Antibody titres were determined as described by Abraham (1974) and were defined as the final dilution of plasma required to bind $50 \%$ of added label. Circulating antibody titres for androstenedione ([1,2,6,7$\left.{ }^{3} \mathrm{H}\right]$ androstenedione; sp. act. $\left.284 \mathrm{mCi} / \mathrm{mg}\right)$, testosterone $\left(\left[1,2,6,7-{ }^{3} \mathrm{H}\right]\right.$ testosterone; sp. act. $\left.284 \mathrm{mCi} / \mathrm{mg}\right)$, progesterone $\left(\left[1,2,6,7-{ }^{3} \mathrm{H}\right]\right.$ progesterone; sp. act. $\left.284 \mathrm{mCi} / \mathrm{mg}\right)$ and oestradiol $\left(\left[2,4,6,7-{ }^{3} \mathrm{H}\right]\right.$ oestradiol; sp. act. $\left.284 \mathrm{mCi} / \mathrm{mg}\right)$ were determined in plasma collected 7 days after booster injection. In addition androstenedione titres were determined for the period before and after boosting and over the entire period of the experiment at 2-7-day intervals.

PEG bound/free separation. To estimate the proportion of antibody-bound steroid in plasma from immunized and control ewes polyethylene glycol was used. The methodology used for these determinations was based on that described by Desbuquois \& Aurbach (1971). An appropriate volume of plasma (50-200 $\mu$ ) was added to $12 \times 75 \mathrm{~mm}$ glass tubes and diluted to a final volume of $300 \mu \mathrm{l}$ with $0.05 \mathrm{M}$-phosphate-buffered saline (PBS). Each sample was diluted in triplicate. To each tube were added $50 \mu \mathrm{l}$ of $6 \%$ bovine $\gamma$-globulin (Fraction II; Calbiochem 345876) in saline and each tube was mixed by vortexing. Then $1 \mathrm{ml} 20 \%$ PEG 6000 in distilled water was added to each tube and after vortexing each tube was allowed to stand at $4^{\circ} \mathrm{C}$ for $20 \mathrm{~min}$. After centrifugation at $2000 \mathrm{~g}$ for $15 \mathrm{~min}$ at $4^{\circ} \mathrm{C}$ the supernatant (free) was allowed to drain into $10 \mathrm{ml}$ extraction tubes for $1 \mathrm{~h}$. The precipitate (bound) was then redissolved in $0.5 \mathrm{ml} 0.05 \mathrm{M}$-phosphate-buffered saline and allowed to stand overnight at $4^{\circ} \mathrm{C}$. One tube of the triplicate diluted for each sample for each fraction had 5000 c.p.m. of the appropriate label added at this stage to estimate recoveries. The two fractions were then subjected to normal RIA as described above and the values obtained were corrected for extraction losses $(\sim 10 \%$ for each fraction). As progesterone and androstenedione concentrations in plasma from androstenedione-immune ewes were very high and they partitioned mainly into the bound fraction, only small volumes $(5-20 \mu \mathrm{l})$ of the bound fraction were assayed. After assay there was good agreement between the total 
Table 1. Parameters for the steroid assays used to measure concentrations in ovarian venous plasma

\begin{tabular}{|c|c|c|c|c|c|c|}
\hline \multirow[b]{2}{*}{ Assay } & \multicolumn{6}{|c|}{ Parameters } \\
\hline & $\begin{array}{c}\text { Extraction } \\
\text { (\% efficiency) }\end{array}$ & $\begin{array}{l}\text { Antiserum } \\
\text { (dilution)* }\end{array}$ & $\begin{array}{l}\text { Sensitivity } \\
\text { (pg/tube) }\end{array}$ & Accuracy ${ }^{\dagger}$ & $\begin{array}{c}\text { Intra- } \\
\text { assay CV } \\
(\%)_{\ddagger}^{ \pm}\end{array}$ & $\begin{array}{c}\text { Inter- } \\
\text { assay CV } \\
(\%)_{+}^{+}\end{array}$ \\
\hline $\begin{array}{l}\text { Oestradiol-17 } \beta \\
(n=10)\end{array}$ & $\begin{array}{l}\text { Diethyl ether } \\
(80-85)\end{array}$ & $\begin{array}{c}727 \\
(1: 75000)\end{array}$ & $2 \cdot 7$ & $\begin{aligned} \mathrm{b} & =0.23 \\
\mathrm{~m} & =1.03 \\
r & =1.00\end{aligned}$ & $\begin{array}{r}15.97 \\
10 \cdot 63 \\
6.78\end{array}$ & $\begin{array}{l}25 \cdot 85 \\
10 \cdot 63 \\
15 \cdot 51\end{array}$ \\
\hline $\begin{array}{l}\text { Androstenedione } \\
(n=10)\end{array}$ & $\begin{array}{c}4 \text { hexane: } \\
1 \text { diethyl ether } \\
(>90)\end{array}$ & $\begin{array}{c}2119 \\
(1: 210000)\end{array}$ & 4 & $\begin{aligned} \mathrm{b} & =1.00 \\
\mathrm{~m} & =1.00 \\
r & =1.00\end{aligned}$ & $\begin{array}{l}3 \cdot 73 \\
6 \cdot 22 \\
6 \cdot 72\end{array}$ & $\begin{array}{c}11 \cdot 9 \\
9 \cdot 10 \\
7 \cdot 40\end{array}$ \\
\hline $\begin{array}{l}\text { Progesterone } \\
(n=4)\end{array}$ & $\begin{array}{l}\text { Hexane } \\
(>90)\end{array}$ & $\begin{array}{c}7943 \\
(1: 9000)\end{array}$ & 100 & $\begin{aligned} \mathrm{b} & =0.66 \\
\mathrm{~m} & =0.90 \\
r & =1.00\end{aligned}$ & $\begin{array}{r}20 \cdot 48 \\
8.50 \\
6.79\end{array}$ & $\begin{array}{r}26 \cdot 04 \\
14 \cdot 16 \\
9 \cdot 00\end{array}$ \\
\hline
\end{tabular}

$n=$ No. of assays.

*Final dilution to bind $50 \%$ of added label (except for progesterone, see below).

$\lceil$ Represents the coefficients from the equation $y=\mathrm{m} x+\mathrm{b}$ which describes the relationship between the amount of hormone added $(x)$ and the amount of hormone measured $(y) ; r$ is the correlation coefficient for this relationship. $\ddagger \mathrm{CV}$ refers to the coefficient of variation and the values refer to $20 \%, 50 \%$ and $80 \%$ displacement respectively.

$\S$ Assay deliberately desensitized to measure high progesterone concentrations in ovarian venous blood. This antiserum dilution bound $85-90 \%$ of added label.

amount of steroid in a sample determined by assay, and the total amount determined by addition of concentrations of bound and free hormone $(y=0 \cdot 36+1 \cdot 0 x ; r=1 \cdot 0)$.

For determination of partitioning of progesterone a mid-iuteal jugular venous sample was used. Oestradiol and androstenedione concentrations were too low to be assayed in jugular venous plasma (with the exception of androstenedione in immunized ewes) and a pool of utero-ovarian venous blood was collected for each animal by taking $200 \mu \mathrm{l}$ from every hourly sample for the early follicular-phase pulse bleed. A similar pool of jugular venous plasma from samples taken during the early follicular phase was used for partitioning of androstenedione for the immunized group only.

Steroid secretion rates. The samples of ovarian venous blood were timed and the ovarian secretion rates of oestradiol, progesterone and androstenedione were calculated after correcting for the haematocrit (Collet et al., 1973).

Normally no correction was made for peripheral concentrations of hormones in these calculations due to their insignificant contribution to the ovarian venous concentration. The only exception to this was in the case of androstenedione secretion rates from androstenedione-immune animals in which peripheral concentrations were very high $(5-10 \mathrm{ng} / \mathrm{ml})$. In this case, ovarian venous concentrations were corrected by subtraction of the average peripheral total androstenedione concentration over the sampling period for each animal, before calculation of the secretion rate.

Statistical analysis. A preovulatory surge of $\mathrm{LH}$ was considered to have occurred when the concentration of $\mathrm{LH}$ in jugular venous plasma exceeded $10 \mathrm{ng} / \mathrm{ml}$ for two or more consecutive samples (Baird \& McNeilly, 1981). The pulse characteristics for $\mathrm{LH}$ and steroids were determined using the Munro (Elsevier-Biosoft, UK) pulse analysis program for the Apple Macintosh computer. Average secretion rates were determined for each animal by calculating the mean secretion rate over each period of intensive sampling. Statistical tests of these pulse characteristics were conducted using analysis of variance (ANOVA) in a split-plot design. Data on the number of pulses per profile were subjected to square root $(x+1)$ transformation before analysis because they consisted of small whole numbers with zeroes present. A RANCIT test indicated that the transformed data were normally distributed before analysis (Wardlaw, 1985).

To compare peripheral LH, FSH and progesterone concentrations these data were centred about the preovulatory LH surge and divided into 4 time periods that corresponded to the follicular phase $(-2.58$ to -0.33 days), LH surge ( -0.25 to 0.42 days), post-ovulatory LH surge ( 0.5 to 3.17 days) and luteal phase ( 3.67 to 13.5 days). As LH, FSH and progesterone were log-normally distributed these data were subjected to log transformation before analysis by repeated samples ANOVA. Following transformation these data were shown not to differ significantly from a normal distribution (Statworks, Cricket Software Inc., Philadelphia, PA, USA) and the mean and variance were found to be independent (Wardlaw, 1985). The statistical significance of the proportions bound and free hormones after PEG separation were tested by unpaired $t$ tests. 


\section{Results}

\section{Cyclicity}

All ewes responded to the PG injections to induce their artificial 'cycles' and cycled 'normally' as verified by detection of oestrus and progesterone monitoring. Similarly, all ewes responded to PG injection before the start of intensive blood sampling and oestrus occurred in all ewes as assessed by examination of vaginal mucus at $43 \mathrm{~h}$ after $\mathrm{PG}$ injection.

\section{Antibody titres}

After boosting, antibody titres rose rapidly to peak within 7 days and then declined slowly (Fig. 1). Most of the binding activity in the plasma of immunized ewes was directed against androstenedione (1:10000 [1:3548-1:17 783]; median titre [range]) but there were measurable antibody titres to testosterone (1:337 [1:152-2975]) and progesterone (1:65 [1:31-1:122]). Although oestradiol binding at the lowest dilution used was $<50 \%$, immunized ewes also had greater binding activity $(20.2 \pm 1.2 \% \mathrm{~B} / \mathrm{T}$ for $1: 25$ dilution; $P<0.001)$ for oestradiol than did control animals. Control animals, at the lowest dilution used $(1: 25)$ exhibited $<5 \%$ binding for all steroids. There was little relationship between the magnitude of either the testosterone titre $(r=0 \cdot 27$, $P=0 \cdot 6)$ or progesterone titre $(r=0 \cdot 34, P=0 \cdot 5)$ with androstenedione titre 7 days after booster immunization.

\section{Peripheral hormone concentrations}

Progesterone. Before the booster immunization, peripheral progesterone concentrations were similar in both groups of ewes (Fig. 1). After boosting, progesterone values in immunized ewes increased rapidly $(P<0.001)$ and coincidentally with antibody titres until luteolysis. Following luteolysis progesterone concentrations fell rapidly in both treatment groups and by $40 \mathrm{~h}$ after PG injection peripheral values were $<0.1 \mathrm{ng} / \mathrm{ml}$. After ovulation progesterone concentrations increased in both groups but the plateau concentration reached was around 10 times greater in immunized ewes $(P<0.001)$ than in control ewes.

$\boldsymbol{L} \boldsymbol{H}$. The time from the injection of PG to the peak of the LH surge was not significantly different between treatment groups $(63 \pm 4 ; 54 \pm 4$ h; mean \pm s.e.m., control and androstenedione-immune respectively). There was no difference in the magnitude of the LH surge between groups $(P=0 \cdot 53)$. Generally, LH concentrations were higher in immunized ewes, although this difference was only significant during the luteal phase (data not shown; $P<0 \cdot 05$ ). Of the 6 immunized animals, 2 had a second LH surge 3-5 days after the first LH surge.

In both groups LH pulse frequency and nadir levels of LH were significantly $(P<0.05)$ higher at both stages of the follicular phase compared to the luteal phase (Table 2). Pulse amplitude did not change significantly from the luteal to the early follicular phase, but was significantly lower during the late follicular phase than in the early follicular phase in both groups. Pulse frequency was also significantly depressed in androstenedione-immune ewes from the early to the late follicular phase. The only significant $(P<0.05)$ difference between treatment groups was a greater number of pulses per profile in immunized ewes during the luteal phase. It was notable, however, that pulse interval was lower in immunized animals at both stages of the follicular phase. Generally, ewes with higher androstenedione antibody titres tended to have a higher mid-luteal LH pulse frequency, and this relationship approached statistical significance $(r=0.06 ; P=0 \cdot 2)$.

$\boldsymbol{F S H}$. The pattern of FSH secretion was similar in ewes from both experimental groups with a fall after luteolysis $(P<0.01)$, a coincident preovulatory surge (with $\mathbf{L H}$ ) and a second peak (Days 1-2; data not shown). The follicular-phase depression in FSH was less marked in immunized animals. FSH concentrations were generally higher in control animals, but due to large betweenanimal variation, this difference was only significant $(P<0.05)$ during the period of the second 


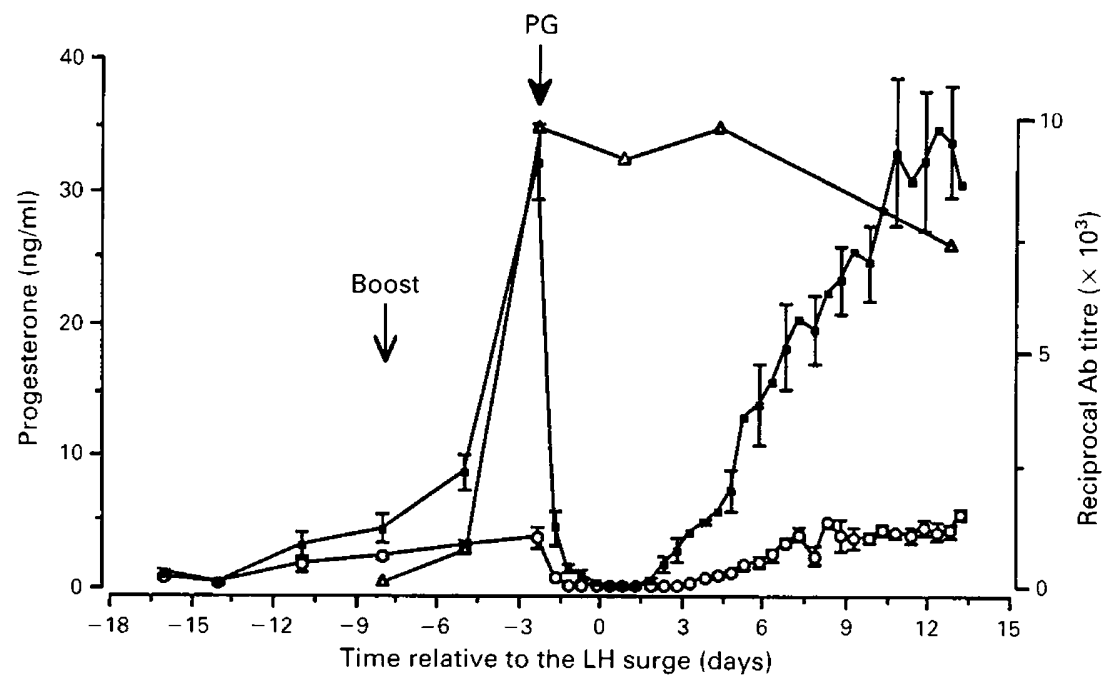

Fig. 1. Peripheral progesterone (mean \pm s.e.m.) concentrations in control $(O)$ and androstenedione-immunized $(\boldsymbol{D})$ ewes with ovarian transplants and median reciprocal antibody titre $(\triangle)$ in androstenedione-immunized ewes with ovarian transplants. Results have been centred about the time of the LH surge. Arrows indicate the time of the booster injection in androstenedioneimmunized ewes and the time of PG (Estrumate) injection in both groups.

Table 2. The characteristics of pulsatile $\mathbf{L H}$ secretion in control $(\mathrm{N}=5)$ and androstenedioneimmunized $(\mathrm{N}=6)$ ewes at three different stages of the oestrous cycle

\begin{tabular}{lccccc}
\hline Stages of cycle & Group & $\begin{array}{c}\text { No. of pulses/ } \\
\text { profile }\end{array}$ & $\begin{array}{c}\text { Pulse interval } \\
(\mathrm{min})\end{array}$ & $\begin{array}{c}\text { Pulse amplitude } \\
(\mathrm{ng} / \mathrm{ml})\end{array}$ & $\begin{array}{c}\text { Nadir } \\
(\mathrm{ng} / \mathrm{ml})\end{array}$ \\
\hline PG + 24 & Control & $4 \cdot 0 \pm 0 \cdot 6$ & $76 \cdot 2 \pm 18 \cdot 4$ & $2 \cdot 0 \pm 0 \cdot 6$ & $0 \cdot 4 \pm 0 \cdot 1$ \\
(6-h sampling) & Immunized & $5 \cdot 2 \pm 0 \cdot 5$ & $71 \cdot 6 \pm 12 \cdot 9$ & $1 \cdot 9 \pm 0 \cdot 3$ & $0 \cdot 6 \pm 0 \cdot 1$ \\
PG + 40 & Control & $3 \cdot 8 \pm 0 \cdot 7$ & $65 \cdot 5 \pm 11 \cdot 7$ & $1 \cdot 0 \pm 0 \cdot 2_{+}^{\ddagger}$ & $0 \cdot 4 \pm 0 \cdot 1$ \\
(4-h sampling) & Immunized & $4 \cdot 8 \pm 0 \cdot 4$ & $47 \cdot 8 \pm 3 \cdot 4 \ddagger$ & $1 \cdot 1 \pm 0 \cdot 1+$ & $0 \cdot 7 \pm 0 \cdot 1$ \\
Mid-luteal (Day 10) & Control & $0 \cdot 8 \pm 0 \cdot 2 \dagger$ & $\geq 480 \$$ & $1 \cdot 2 \pm 0 \cdot 1$ & $0 \cdot 2 \pm 0 \cdot 1 \dagger$ \\
(8-h sampling) & Immunized & $2 \cdot 3 \pm 0 \cdot 4^{* \dagger}$ & $173 \cdot 4 \pm 17 \cdot 7 \dagger$ & $1 \cdot 9 \pm 0 \cdot 5$ & $0 \cdot 2 \pm 0 \cdot 1 \dagger$ \\
\hline
\end{tabular}

Values are mean \pm s.e.m.

*Significantly different from untreated control, within a phase of the oestrous cycle, $P<0.05$.

†Comparison within treatment groups, significantly different from both stages of the follicular phase, $P<0.05$.

$\Varangle$ Comparison within treatment groups, significantly different from the early follicular phase (PG $+24 \mathrm{~h}), P<0.05$.

$\S$ This value is an estimate only as there were insufficient pulses per profile to obtain an accurate measure of pulse interval.

FSH peak (0.5-3.17 days). Much of this variation was due to 2 control animals which had unusually high peripheral FSH values $(4-6 \mathrm{ng} / \mathrm{ml})$.

\section{Ovarian steroid secretion rates}

Pulsatile steroid secretion. The parameters of pulsatile steroid secretion are shown in Table 3. Each pulse of $\mathrm{LH}$ resulted in a pulse of steroid secretion and steroid and $\mathrm{LH}$ pulse frequency were highly correlated $(r=0.96 ; P<0.001)$. As with $\mathrm{LH}$, the only difference between treatment groups in steroid pulse frequency was a greater number of pulses per profile $(P<0.05)$ in immunized animals during the luteal phase. Oestradiol and androstenedione pulse frequency were greater $(P<0.05)$ during the follicular phase than during the luteal phase. 
Table 3. The characteristics of pulsatile steroid secretion $\left(\mathrm{A}_{4}=\right.$ androstenedione; $\mathrm{E}_{2}=$ oestradiol; $\mathrm{P}_{4}=$ progesterone) in control and androstenedione-immunized ewes at three stages of the oestrous cycle

\begin{tabular}{|c|c|c|c|c|c|c|}
\hline Stage of cycle & Steroid & Group & $\begin{array}{l}\text { No. of pulses/ } \\
\text { profile }\end{array}$ & $\begin{array}{l}\text { Pulse interval } \\
\quad \text { (min) }\end{array}$ & $\begin{array}{l}\text { Pulse amplitude } \\
\text { (ng/min })_{+}^{+}\end{array}$ & $\underset{\text { (ng/min) } \ddagger}{\text { Nadir }}$ \\
\hline \multirow[t]{2}{*}{$\begin{array}{l}\mathrm{PG}+24 \mathrm{~h} \\
\text { (6-h sampling) }\end{array}$} & $\mathrm{E}_{2}$ & $\begin{array}{c}\text { Control } \\
\text { Immunized }\end{array}$ & $\begin{array}{l}3 \cdot 8 \pm 0.6 \\
5 \cdot 2 \pm 0.5\end{array}$ & $\begin{array}{l}89.3 \pm 12.4 \\
67.5 \pm 7.9\end{array}$ & $\begin{array}{l}4 \cdot 8 \pm 1 \cdot 3 \\
2 \cdot 1 \pm 0.4^{*}\end{array}$ & $\begin{array}{l}1.7 \pm 0.7 \\
1.6 \pm 0.4\end{array}$ \\
\hline & $\mathrm{A}_{4}$ & $\begin{array}{c}\text { Control } \\
\text { Immunized }\end{array}$ & $\begin{array}{l}4 \cdot 0 \pm 0.6 \\
5 \cdot 0 \pm 0.5\end{array}$ & $\begin{array}{l}90 \cdot 4 \pm 12 \cdot 6 \\
74 \cdot 3 \pm 12 \cdot 3\end{array}$ & $\begin{aligned} 6.3 & \pm 1 \cdot 2 \\
50.7 & \pm 8 \cdot 2^{* *}\end{aligned}$ & $\begin{array}{c}1.6 \pm 0.4 \\
16 \cdot 9 \pm 4 \cdot 2^{* *}\end{array}$ \\
\hline \multirow[t]{2}{*}{$\begin{array}{l}\mathrm{PG}+40 \mathrm{~h} \\
\text { (4-h sampling) }\end{array}$} & $E_{2}$ & $\begin{array}{c}\text { Control } \\
\text { Immunized }\end{array}$ & $\begin{array}{l}3 \cdot 20 \pm 0.20 \\
4 \cdot 40 \pm 0.75\end{array}$ & $\begin{array}{l}67.9 \pm 11 \cdot 8 \\
52.0 \pm 7.9\end{array}$ & $\begin{array}{l}6.5 \pm 1.2 \\
2.8 \pm 0.7^{*}\end{array}$ & $\begin{array}{l}2.3 \pm 1.1 \\
1.8 \pm 0.5\end{array}$ \\
\hline & $\mathrm{A}_{4}$ & $\begin{array}{c}\text { Control } \\
\text { Immunized }\end{array}$ & $\begin{array}{l}3.60 \pm 0.40 \\
3.80 \pm 0.37\end{array}$ & $\begin{array}{l}67 \cdot 5 \pm 10 \cdot 8 \\
56 \cdot 0 \pm 6 \cdot 4\end{array}$ & $\begin{aligned} 6 \cdot 5 & \pm 1 \cdot 1 \\
37 \cdot 4 & \pm 4 \cdot 3^{* * *}\end{aligned}$ & $\begin{array}{c}3 \cdot 1 \pm 1 \cdot 1 \\
12 \cdot 2 \pm 3 \cdot 8^{*}\end{array}$ \\
\hline $\begin{array}{l}\text { Mid-luteal } \\
\text { (Day 10) }\end{array}$ & $\mathrm{P}_{4}$ & $\begin{array}{c}\text { Control } \\
\text { Immunized }\end{array}$ & $\begin{array}{l}0.8 \pm 0.2 \\
2.3 \pm 0.4^{*}\end{array}$ & $\begin{array}{c}\geq 480 \S \\
198 \cdot 6 \pm 30 \cdot 8\end{array}$ & $\begin{array}{cl}6.1 & \pm 0.9 \\
11.8 & \pm 1.7^{* *}\end{array}$ & $\begin{array}{c}4.8 \pm 0.4 \\
12 \cdot 4 \pm 1 \cdot 7^{* *}\end{array}$ \\
\hline \multirow[t]{2}{*}{ (8-h sampling) } & $\mathrm{E}_{2}$ & $\begin{array}{c}\text { Control } \\
\text { Immunized }\end{array}$ & $\begin{array}{l}0.8 \pm 0.2 \dagger \\
2.3 \pm 0.4^{*} \dagger\end{array}$ & $\begin{array}{c}\geq 480 \S \\
189 \cdot 0 \pm 43 \cdot 1 \dagger\end{array}$ & $\begin{array}{l}0.8 \pm 0.12 \dagger \\
0.76 \pm 0.2 \dagger\end{array}$ & $\begin{array}{l}0.2 \pm 0 \cdot 1 \dagger \\
0.4 \pm 0.2 \dagger\end{array}$ \\
\hline & $\mathrm{A}_{4}$ & $\begin{array}{l}\text { Control } \\
\text { Immunized }\end{array}$ & $\begin{array}{l}0.8 \pm 0.2 \dagger \\
2.3 \pm 0.4^{*+}\end{array}$ & $\begin{array}{c}\geq 480 \S \\
201 \cdot 0 \pm 37 \cdot 8 \dagger\end{array}$ & $\begin{aligned} 3.5 & \pm 0.6 \dagger \\
31.4 & \pm 7.2^{* *}\end{aligned}$ & $\begin{array}{c}1.9 \pm 0.3 \\
11.6 \pm 2.9 *\end{array}$ \\
\hline
\end{tabular}

Values are mean \pm s.e.m.

${ }^{*} P<0.05 ;{ }^{* *} P<0.01 ;{ }^{* *} P<0.001$ compared with untreated control, within a phase of the oestrous cycle.

tComparison within treatment groups, significantly different from both stages of the follicular phase, $P<0 \cdot 05$.

$\ddagger \mu \mathrm{g} / \mathrm{min}$ for $\mathbf{P}_{\mathbf{4}}$.

$\S$ This value is only an estimate as there were insufficient pulses per profile to obtain an accurate measure of pulse interval.

At all stages of the cycle androstenedione pulse amplitude and basal secretion rates were elevated in androstenedione-immune ewes $(P<0.05$; Table 3$)$. Despite this very high secretion rate, androstenedione secretion was still pulsatile in nature, responding to each $\mathrm{LH}$ pulse. Peripheral androstenedione concentrations in immunized ewes were $6 \cdot 2 \pm 1 \cdot 7,7 \cdot 8 \pm 2 \cdot 1$ and $4.5 \pm 1 \cdot 1 \mathrm{ng} / \mathrm{ml}$ (mean \pm s.e.m.) for the early follicular, late follicular and luteal phases, respectively. Jugular venous androstenedione concentrations were undetectable in normal ewes. In control ewes, mean androstenedione pulse amplitude during the follicular phase was higher $(P<0 \cdot 05)$ than during the luteal phase. There was no significant difference in control ewes in pulse amplitude between the two stages of the follicular phase. In androstenedione-immune ewes androstenedione pulse amplitude also increased $(P<0.05)$ from the luteal to the early follicular phase. During the late follicular phase pulse amplitude decreased to luteal-phase levels in androstenedione-immune animals. Basal secretion rate did not vary significantly with stage of cycle in either treatment group.

Oestradiol pulse amplitude was lower $(P<0.05)$ in androstenedione-immune animals during both stages of the follicular phase but not the luteal phase (Table 3). Basal oestradiol secretion was not significantly different between groups at any stage of the oestrous cycle. There were significant $(P<0.05)$ stage-of-cycle effects in oestradiol pulse amplitude and basal secretion, with follicular phase levels being higher than those in the luteal phase.

Progesterone pulse amplitude and basal secretion rate were elevated $(P<0.01)$ in androstenedione-immune ewes during the luteal phase of the cycle (Table 3). Ewes in both treatment groups exhibited significant $(P<0.05)$ stage-of-cycle effects in progesterone pulse amplitude and basal secretion, with luteal phase concentrations being higher than in the follicular phase.

Mean secretion rate. The overall rate of androstenedione secretion rates was 10 times greater $(P<0.001)$ in androstenedione-immune ewes at all stages of the cycle (Table 4). Despite the lower oestradiol pulse amplitude during the follicular phase, mean oestradiol secretion rates, while being 
lower, were not significantly different between treatment groups due to the slightly higher pulse frequency in androstenedione-immune ewes during the follicular phase. During the luteal phase, when pulse amplitude was similar between groups, the androstenedione-immune ewes with more luteal pulses tended to have higher oestradiol secretion rates with this difference approaching statistical significance $(P=0.06)$. Ewes in both groups had lower $(P<0.01)$ total secretion rates of oestradiol and androstenedione during the luteal phase than during the follicular phase.

Table 4. Total steroid secretion rates androstenedione $\left(\mathrm{A}_{4}\right)$, oestradiol $\left(\mathrm{E}_{2}\right)$ and progesterone $\left(\mathrm{P}_{4}\right)$ in control and androstenedione-immunized ewes at three stages of the oestrous cycle

\begin{tabular}{lccc}
\hline Stage of cycle & Steroid & Control & Immunized \\
\hline Early follicular & $\mathrm{P}_{4}(\mu \mathrm{gg} / \mathrm{min})$ & $0 \cdot 15 \pm 0 \cdot 06$ & $0.53 \pm 0 \cdot 13^{* *}$ \\
$(\mathrm{PG}+24)$ & $\mathrm{E}_{2}(\mathrm{ng} / \mathrm{min})$ & $3 \cdot 53 \pm 1 \cdot 21$ & $2 \cdot 55 \pm 0 \cdot 54$ \\
& $\mathrm{~A}_{4}(\mathrm{ng} / \mathrm{min})$ & $3 \cdot 83 \pm 0 \cdot 61$ & $36 \cdot 87 \pm 7 \cdot 11^{* * *}$ \\
& $\mathrm{Ratio}_{2}: \mathrm{A}_{4}$ & $0 \cdot 97: 1$ & $0 \cdot 07: 1$ \\
\hline Late follicular & $\mathrm{P}_{4}(\mu \mathrm{gg} / \mathrm{min})$ & $0 \cdot 11 \pm 0 \cdot 04$ & $0 \cdot 22 \pm 0 \cdot 07$ \\
$(\mathrm{PG}+40)$ & $\mathrm{E}_{2}(\mathrm{ng} / \mathrm{min})$ & $5 \cdot 00 \pm 1 \cdot 47$ & $3.22 \pm 0 \cdot 60$ \\
& $\mathrm{~A}_{4}(\mathrm{ng} / \mathrm{min})$ & $5 \cdot 37 \pm 1 \cdot 41$ & $32 \cdot 63 \pm 6 \cdot 67^{* * *}$ \\
& $\mathrm{Ratio}_{2}: \mathrm{A}_{4}$ & $0 \cdot 98: 1$ & $0 \cdot 10: 1$ \\
\hline Mid-luteal & $\mathrm{P}_{4}(\mu \mathrm{gg} / \mathrm{min})$ & $5 \cdot 88 \pm 0 \cdot 85 \dagger$ & $15 \cdot 84 \pm 2 \cdot 38^{* \dagger}$ \\
(Day 10) & $\mathrm{E}_{2}(\mathrm{ng} / \mathrm{min})$ & $0 \cdot 24 \pm 0 \cdot 04 \dagger$ & $0 \cdot 41 \pm 0 \cdot 06 \dagger$ \\
& $\mathrm{A}_{4}(\mathrm{ng} / \mathrm{min})$ & $2 \cdot 45 \pm 0 \cdot 20 \dagger$ & $18 \cdot 45 \pm 2 \cdot 12^{* * *}$ \\
& $\mathrm{Ratio}_{2}: \mathrm{A}_{4}$ & $0 \cdot 10: 1$ & $0 \cdot 02 \cdot 1$ \\
\hline
\end{tabular}

Values are mean \pm s.e.m.

${ }^{*} P<0.05 ;{ }^{* *} P<0.01 ;{ }^{* * *} P<0.001$ compared with untreated controls.

$\dagger P<0.05$ compared with values at the two follicular-phase stages.

Mean progesterone secretion was significantly $(P<0.01)$ higher in immunized than in control ewes during the early follicular but not late follicular phase. During the luteal phase progesterone secretion was around 3 times greater in androstenedione-immune ewes. Progesterone secretion rates were higher $(P<0.01)$ during the luteal phase than during the follicular phase.

\section{Bound and free steroid fractions}

Androstenedione in ovarian venous plasma from androstenedione-immune ewes partitioned almost completely into the bound fraction (98\%) compared to control ewes in which $40 \%$ of this steroid was in a free form (Fig. 2). Similarly, in jugular venous plasma from immunized ewes $98 \%$ of the steroid was in a bound form $(13.8 \pm 1.8 \mathrm{ng} / \mathrm{ml}$ bound and $0.5 \mathrm{ng} / \mathrm{ml}$ free). Although the amount of androstenedione in immune animals partitioning into a free fraction was quite high, especially in the peripheral circulation, this figure should be treated with caution as it represents only $2 \%$ of the total steroid, and such a figure is less than the error of the method.

In control animals $85 \%$ of ovarian venous plasma oestradiol partitioned into the free fraction. However, in androstenedione-immune animals less oestradiol $(54 \%)$ partitioned into the free fraction $(P<0.05)$. In jugular venous blood the concentration and proportion of progesterone bound was greater in androstenedione-immune ewes $(86 \% ; P<0.05)$. The amount of progesterone free in plasma from androstenedione-immune ewes $(3.5 \pm 0.3 \mathrm{ng} / \mathrm{ml})$ was about the same as in control animals $(3 \cdot 8 \pm 0.3 \mathrm{ng} / \mathrm{ml})$. 

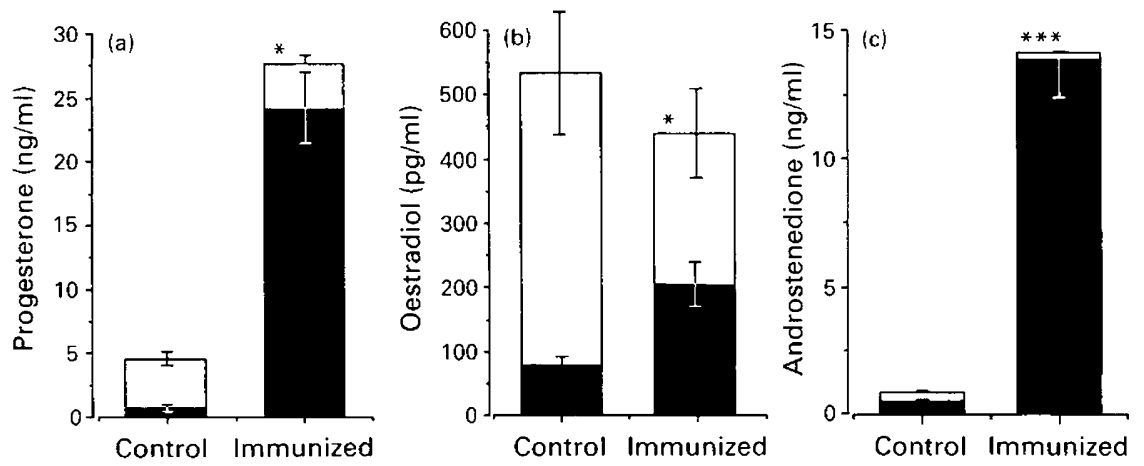

Fig. 2. The distribution of mean ( \pm s.e.m.) free (open bar) and bound (closed bar) progesterone in jugular venous plasma (a) and oestradiol (b) and androstenedione (c) in ovarian venous plasma from normal (control) and androstenedione-immunized ewes as determined by separation with PEG and subsequent radioimmunoassay. ${ }^{*} P<0.05 ;{ }^{* * *} P<0.001$ for proportions of steroid bound and free.

\section{Discussion}

The responses to immunization in terms of antibody titre and peripheral hormone concentrations observed in ewes with ovarian autotransplants agrees closely with previous results (Scaramuzzi et al., 1980; Campbell, 1988), indicating that the position of the remaining ovary had little effect on the response to immunization. In control animals the level of steroid secretion rate and pattern of change of secretion rate with stage of the oestrous cycle agreed with published results (Baird, 1978; Baird et al., 1976a, b, 1981).

Immunization against androstenedione increased the rate of ovarian secretion and peripheral concentrations of both androstenedione and progesterone. Although the increase in secretion rate undoubtedly contributes to the increase in peripheral concentration of both androstenedione and progesterone in androstenedione-immune animals, the magnitude of the increase in secretion rate (androstenedione $\times 10$ and progesterone $\times 3$ ) was not sufficient to account for the total increase in peripheral steroid concentrations (androstenedione $\times 1000$ and progesterone $\times 10$ ). This discrepancy suggests that the presence of antibodies interferes with the catabolism of these steroids, as reported for the testosterone-immune rabbit (Wickings et al., 1976). However, an increase in the secretion of adrenal steroids cannot be ruled out as active androstenedione immunity has been observed to increase adrenal weight (R. J. Scaramuzzi \& Y. Cognie, unpublished observations). The fact that progesterone concentrations increased after boosting in conjunction with antibody titres provides strong evidence that the elevation of progesterone in androstenedione-immune ewes is not a function of the type or number of corpora lutea but rather a combination of elevated secretion rate and impaired catabolism.

Although greatly enhanced, androstenedione and progesterone secretion in immunized ewes responded to $\mathrm{LH}$ pulses and was pulsatile in nature suggesting that steroid secretion was under the control of $\mathrm{LH}$ (Table 3). However, the differences in magnitude of the changes in LH pulse frequency and secretion rate also suggest that the increase in $\mathrm{LH}$ pulse frequency was not the only cause of the increase in secretion rate. It would appear that the presence of steroid antibodies has a direct effect on the steroidogenic capacity of the thecal and luteal cells. Whether this increase in secretion rate operates through stimulation of a rate-limiting enzyme, increasing sensitivity to cAMP or other effects on the steroidogenic mechanism is unclear, but it appears unlikely that increased cAMP secretion per se is the cause of elevated androstenedione and progesterone secretion in androstenedione-immune ewes (Campbell, 1988).

Despite having more LH pulses the rate of mean oestradiol secretion during the luteal phase was not significantly affected by immunization. During the follicular phase, despite a significant 
depression in oestradiol pulse amplitude (Table 3), immunization again had no significant effect on the rate of mean oestradiol secretion due to the tendency for immunized ewes to have more LH pulses, although, perhaps due to the small sample size, this tendency was not statistically significant. Although not determined in the present experiment it has been shown that ewes immunized against androstenedione have a greater number of large oestrogenic follicles during both the luteal and follicular phase of the cycle (Scaramuzzi \& Hoskinson, 1984; Campbell, 1988). The results of this experiment therefore suggest that androstenedione-immune ewes produce less oestradiol per oestrogenic follicle. This decrease in oestradiol production per follicle, however, appears to be offset by an increase in the number of oestrogenic follicles (Scaramuzzi \& Hoskinson, 1984; Campbell, 1988) and an increase in the level of LH stimulation, at least during the luteal phase (Scaramuzzi \& Hoskinson, 1984; Campbell, 1988; Table 2). The most probable mechanism for inhibition of oestradiol synthesis per follicle is neutralization of androgen precursors for aromatization by antibodies, both in the circulation and in the antral fluid (Scaramuzzi et al., 1980). The predominant partitioning of androstenedione into the bound fraction in ovarian and jugular venous plasma from androstenedione-immune ewes following PEG separation and the depression in oestradiol pulse amplitude in immunized ewes during the follicular phase, when the requirements for aromatizable androgens are high, provides evidence for this hypothesis.

The results of the PEG separation experiments suggest that the cross-reactions observed in androstenedione-immune animals with progesterone and oestradiol are more important than previously believed. Separation using PEG or charcoal is a purely chemical means and may not reflect the availability of steroids for their target cell. It is not unreasonable to assume, however, that the presence of plasma binding activity in androstenedione-immune ewes does, to some degree, upset the balance of steroid activity. Certainly, these cross-reactions can explain a number of the puzzling characteristics of androstenedione-immune ewes. The foremost of these is the mechanism whereby LH pulse frequency is elevated in androstenedione-immune ewes during the luteal phase when both progesterone and/or oestradiol are also elevated. As biologically effective oestradiol levels are around 1-2 pg/ml (Karsch et al., 1984), binding activity, even if only a small part of it were high affinity, could upset the normal feedback relationships between oestradiol, LH and FSH. Similarly, the considerable plasma binding activity for progesterone observed in immunized ewes (Fig. 2) would be expected to interfere with negative feedback during the luteal phase. The observation of a second LH surge in some androstenedione-immune animals within 3-5 days of the first LH surge, despite elevated progesterone concentrations $(4-5 \mathrm{ng} / \mathrm{ml})$, provides evidence for this view as similar perturbation of normal cyclicity have been observed in ewes actively immunized against progesterone (Thomas et al., 1987). Rosenberg et al. (1987) have also described an increase in total progesterone levels in the absence of changes in free progesterone in progesterone-immunized ewes with very low titres $(1: 5-1: 66)$ of progesterone which continued to have oestrous cycles. The ability of androstenedione-immunized ewes to cycle normally therefore appears to involve a delicate balance between the proportion of free and bound progesterone because during the mid-luteal phase the amount of free progesterone in androstenedione-immunized ewes was similar to normal mid-luteal levels (Fig. 2). The exact effects of immunization on LH secretion during the follicular phase when progesterone is absent are unclear, although there does appear to be a small but consistent increase in LH pulse frequency in androstenedione-immunized ewes (Table 2; Campbell, 1988).

In contrast to LH, peripheral FSH concentrations appear to be under the dual control of oestradiol and the ovarian peptide, inhibin (Martin et al., 1988). In both the present, and previous, experiments (Martensz et al., 1979; Pathiraja et al., 1984; Campbell, 1988), plasma FSH concentrations were not significantly different in normal and androstenedione-immune ewes. Peripheral concentrations of inhibin are higher in androstenedione-immunized ewes (Campbell et al., 1988), suggesting that any interference with oestradiol feedback by immunization may be counteracted by higher inhibin, thus leading to unchanged jugular venous FSH concentrations. 
In conclusion, this experiment has shown that immunization against androstenedione leads to increases in the secretion rate of both androstenedione and progesterone. Oestradiol secretion rate was not significantly different at any stage of the cycle. Partitioning of bound and free components of steroid secretion showed significantly increased binding activity in the plasma of androstenedione-immunized ewes for androstenedione, progesterone and oestradiol, and it is suggested that this binding could explain the elevation in LH pulse frequency in androstenedioneimmune animals.

We thank Professor D. T. Baird for help in the preparation of the ewes with autotransplanted ovaries; Mr K. E. Turnbull, Mr S. Shipp and Mr W. Hermann for skilled technical assistance; the animal care staff of Division of Animal Production, CSIRO, Prospect, particularly Mr T. Holmes and Mr S. Collins, for husbandry of sheep; Mr J. Donnelly and Dr G. Brown of the Division of Mathematics and Statistics, CSIRO, for statistical advice; and Dr S. Raiti of the NIAMDD for provision of reagents for the gonadotrophin assays. B.K.C. was in receipt of a Commonwealth Postgraduate Scholarship.

\section{References}

Abraham, G.E. (1974) Radioimmunoassay of steroids in biological materials. Acta endocr., Copenh., Suppl. 183, $1-42$.

Baird, D.T. (1978) Pulsatile secretion of LH and ovarian estradiol during the follicular phase of the sheep estrous cycle. Biol. Reprod. 18, 359-364.

Baird, D.T. \& McNeilly, A.S. (1981) Gonadotrophic control of follicular development and function during the oestrous cycle of the ewe. J. Reprod. Fert., Suppl. 30, 119-133.

Baird, D.T., Land, R.B., Scaramuzzi, R.J. \& Wheeler, A.G. (1976a) Endocrine changes associated with luteal regression in the ewe; the secretion of ovarian oestradiol, progesterone and androstenedione and uterine prostaglandin F $2 \alpha$ throughout the oestrous cycle. J. Endocr. 69, 275-286.

Baird, D.T., Swanston, I. \& Scaramuzzi, R.J. (1976b) Pulsatile release of $\mathrm{LH}$ and secretion of ovarian steroids in sheep during the luteal phase of the estrous cycle. Endocrinology 98, 1490-1496.

Baird, D.T., Swanston, I.A. \& McNeilly, A.S. (1981) Relationship between LH, FSH, and prolactin concentration and the secretion of androgens and estrogens by the preovulatory follicle in the ewe. Biol. Reprod. 24, 1013-1025.

Campbell, B.K. (1988) Factors affecting ovulation rate in sheep and catte. Ph.D. thesis, University of Sydney.

Campbell, B.K., Baird, D.T., McNeilly, A.S. \& Scaramuzzi, R.J. (1988) The effect of androstenedione-immunity on the ovarian secretion rate and peripheral plasma concentrations of inhibin. J. Reprod. Fert., Abstr. Ser. 2, Abstr. 76.

Collet, R.A., Land, R.B. \& Baird, D.T. (1973) The pattern of progesterone secretion by the autotransplanted ovary of the ewe in response to luteinizing hormone. J. Endocr. 56, 403-411.

Desbuquois, B. \& Aurbach, G.D. (1971) Use of polyethylene glycol to separate free and antibody-bound peptide hormones in radioimmunoassays. J. clin. Endocr. Metab. 33, 732-738.
Goding, J.R., McCracken, J.A. \& Baird, D.T. (1967) The study of ovarian function in the ewe by means of a vascular autotransplantation technique. $J$. Endocr. 39, 37-52.

Karsch, F.J., Bittman, E.L., Foster, D.L., Goodman, R.L., Legan, S.J. \& Robinson, J.E. (1984) Neuroendocrine basis of seasonal reproduction. Recent Progr. Horm. Res. 40, 185-232.

Martensz, N.D. \& Scaramuzzi, R.J. (1979) Plasma concentrations of luteinizing hormone, follicle-stimulating hormone and progesterone during the breeding season in ewes immunized against androstenedione or testosterone. J. Endocr. 81, 249-259.

Martensz, N.D., Scaramuzzi, R.J. \& Van Look, P.F.A. (1979) Plasma concentrations of luteinizing hormone and follicle-stimulating hormone during anoestrus in ewes actively immunized against oestradiol-17 $\beta$, oestrone or testosterone. J. Endocr. 81, 261-269.

Martin, G.B., Scaramuzzi, R.J. \& Henstridge, J.D. (1983) Effects of oestradiol, progesterone and androstenedione on the pulsatile section of luteinizing hormone in ovariectomized ewes during spring and autumn. J. Endocr. 96, 181-193.

Martin, G.B., Price, C.A., Thiery, J-C. \& Webb, R. (1988) Interactions between inhibin, oestradiol and progesterone in the control of gonadotrophin secretion in the ewe. J. Reprod. Fert. 82, 319-328.

McNatty, K.P., Hudson, N.L., Gibb, M. \& Collins, F.L. (1988) The plasma concentrations of FSH, LH, and progesterone in sheep immunized against an androstenedione-protein conjugate. J. Reprod. Fert. 82, 63-69.

Pant, H.C. (1978) Effect of androgens on concentrations of LH and FSH in the peripheral plasma of anoestrous ewes. J. Reprod. Fert. 50, 133-136.

Pathiraja, N., Carr, W.R., Fordyce, M., Forster, J., Land, R.B. \& Morris, B.A. (1984) Concentration of gonadotrophins in the plasma of sheep given antisera to raise ovulation rate. $J$. Reprod. Fert. 72, 93-100.

Rosenberg, M., Amir, D. \& Folman, Y. (1987) The effect of active immunization against progesterone on Downloaded from Bioscientifica.com at 04/26/2023 12:05:56AM via free access 
plasma concentrations of total and free progesterone, estradiol- $17 \beta$ and LH in the cyclic ewe. Theriogenology 28, 4โ7-426.

Scaramuzzi, R.J. \& Hoskinson, R.M. (1984) Active immunization against steroid hormones for increasing fecundity. In Immunological Aspects of Reproduction in Mammals, pp. 445-474. Ed. D. B. Crighton. Butterworth Scientific, London.

Scaramuzzi, R.J., Corker, C.S., Young, G. \& Baird, D.T. (1975) Production of antisera to steroid hormones in sheep. In Steroid Immunoassay, pp. 111-122. Eds E. H. D. Cameron, S. G. Hillier \& K. Griffiths. Alpha Omega Alpha Publishing, Cardiff.

Scaramuzzi, R.J., Baird, D.T., Clarke, I.J., Martensz, N.D. \& Van Look, P.F.A. (1980) Ovarian morphology and the concentration of steroids during the oestrous cycle of sheep actively immunized against androstenedione. J. Reprod. Fert. 58, 27-35.

Scaramuzzi, R.J., Geldard, H., Beels, C.M., Hoskinson, R.M. \& Cox, R.I. (1983) Increased lambing percentages through immunization against steroid hormones. Wool Technology and Sheep Breeding 31, 87-97.

Tsonis, C.G., Baird, D.T., Campbell, B.K., Downing, J.A. \& Scaramuzzi, R.J. (1988) Secretion of bioactive inhibin by the ovary of the Booroola Merino ewe with or without a copy of the fecundity $(\mathrm{F})$ gene. $J$. Endocr. 116, R5-R8.

Thomas, G.B., Oldham, C.M., Hoskinson, R.M., Scaramuzzi, R.J. \& Martin, G.B. (1987) Effect of immunization against progesterone on oestrus, cycle length, ovulation rate, luteal regression and $\mathrm{LH}$ secretion in the ewe. Aust. J. biol. Sci. 40, 307-313.

Turnbull, K.E., Shutt, D.A. \& Braden, A.W.H. (1967) Increase in choline content of cervical mucus as a simple test for impending ovulation and for oestrogenic stimulation in ewes. Aust. J. exp. Agric. Anim. Hus. 7, 314-317.

Wardlaw, A.C. (1985) Practical Statistics for Experimental Biologists. John Wiley \& Sons, Chichester.

Webb, R., Land, R.B. \& Pathiraja, N. (1984) Passive immunization against steroid hormones in the female. In Immunological Aspects of Reproduction in Mammals, pp. 475-499. Ed. D. B. Crighton. Butterworth Scientific, London.

Wickings, E.J., Becher, A. \& Nieschlag, E. (1976) Testosterone metabolism in rabbits actively immunized with testosterone. Endocrinology 98, 1142-1146.

Received 21 September 1989 